\title{
PENGEMBANGAN PERANGKAT PEMBELAJARAN DENGAN PENDEKATAN KONTEKSTUAL PADA MATERI KUBUS DAN BALOK
}

\author{
Neneng Aminah ${ }^{1}$, Irawati ${ }^{2}$ \\ 1,2 Universitas Swadaya Gunung Jati \\ email: nenengaminah255@gmail.com
}

\begin{abstract}
ABSTRAK
Penelitian ini bertujuan untuk menghasilkan produk perangkat pembelajaran berupa Lembar Kerja Siswa (LKS), Pedoman Pembelajaran Guru, dan Rencana Pelaksanaan Pembelajaran (RPP) pada materi Kubus dan Balok yang berbasis Pendekatan Kontekstual untuk siswa SMP kelas VIII semester 2. Penelitian ini bertujuan untuk mengetahui kualitas produk dari aspek kevalidan. Jenis penelitian ini menggunakan model pengembangan ADDIE, namun dalam penelitian ini hanya sampai tahapan Analisis (Analysis), Desain (Design), dan Pengembangan (Development). Subjek dari penelitian ini adalah siswa SMP Negeri 1 Sindang kelas VIII-B sebanyak 33 siswa. Instrumen yang digunakan dalam penelitian ini adalah tes kemampuan awal siswa pada tahapan analisis karakteristik siswa, analisis kurikulum untuk mengetahui materi yang akan digunakan pada siswa, dan penilaian perangkat pembelajaran untuk mengetahui kevalidan. Validasi perangkat pembelajaran ini dilakukan oleh lima ahli matematika, diantaranya tiga dosen pendidikan matematika, dan dua guru matematika. Berdasarkan hasil validasi yang diperoleh untuk LKS adalah $86 \%$ dengan kriteria sangat valid, validasi yang diperoleh untuk Pedoman Pembelajaran Guru adalah $87,75 \%$ dengan kriteria sangat valid, dan validasi yang diperoleh untuk RPP adalah 84,6\% dengan kriteria cukup valid.
\end{abstract}

Kata Kunci: $\quad$ Perangkat Pembelajaran, Pendekatan Kontekstual, Kubus dan Balok

Dikirim: 2 Mei 2018; Diterima: 17 September 2018; Dipublikasikan: 29 September 2018

Cara sitasi: Aminah, N., dan Irawati. 2018. Pengembangan Perangkat Pembelajaran dengan Pendekatan Kontekstual pada Materi Kubus dan Balok. Teorema: Teori dan Riset Matematika Vol 3, No 2 (2018). Hal 137-144 


\section{PENDAHULUAN}

Guru adalah praktisi pendidikan yang semestinya harus mengimplementasikan sistem pendidikan nasional dengan sebenar-benarnya. Guru berperan penting dalam upaya meningkatkan kualitas pendidikan yang berkaitan dengan tugas pokok dan fungsinya sebagai pendidik yang diharapkan mampu membawa peningkatan dalam proses pembelajaran (Chodijah, Siti, dkk., 2012: 21).

Mengingat pentingnya peranan guru dalam proses pembelajaran, agar tujuan pembelajaran dapat mencapai sasaran dengan baik maka perlu diperhatikan apakah perangkat pembelajaran tersebut sudah memenuhi kejelasan indikator dan tujuan pembelajaran pada RPP (Rencana Pelaksanaan Pembelajaran) yang ingin dicapai, yang merupakan ukuran keberhasilan siswa dalam belajar matematika. PP Nomor 19 Tahun 2005 Pasal 20 menyatakan bahwa guru diharapkan mengembangkan materi pembelajaran dan mensyaratkan bagi guru pada satuan pendidikan untuk mengembangkan RPP. Perbaikan proses belajar dapat dilakukan melalui belajar penyelidikan, siswa diajak untuk berbicara, bertindak secara matematis serta berpartisipasi dalam diskusi matematika untuk memecahkan masalah baru atau asing (Aminah, 2017: 51). Proses ini dapat tertuang pada kegiatan inti RPP.

Berdasarkan hasil observasi di SMP Negeri 1 Sindang, di dapat hasil analisis kurikulum yang diperoleh informasi bahwa kurikulum yang digunakan adalah KTSP (Kurikulum Tingkat Satuan Pendidikan). Materi kubus dan balok termasuk dalam Standar Kompetensi: Memahami sifat-sifat kubus, balok, prisma, limas, dan bagian-bagiannya, serta menentukan ukuran-ukurannya.

\section{Tabel 1.Standar Kompetensi (SK), Kompetensi Dasar (KD), serta Indikator Pencapaian KD} pada Materi Kubus dan Balok SMP N 1 Sindang

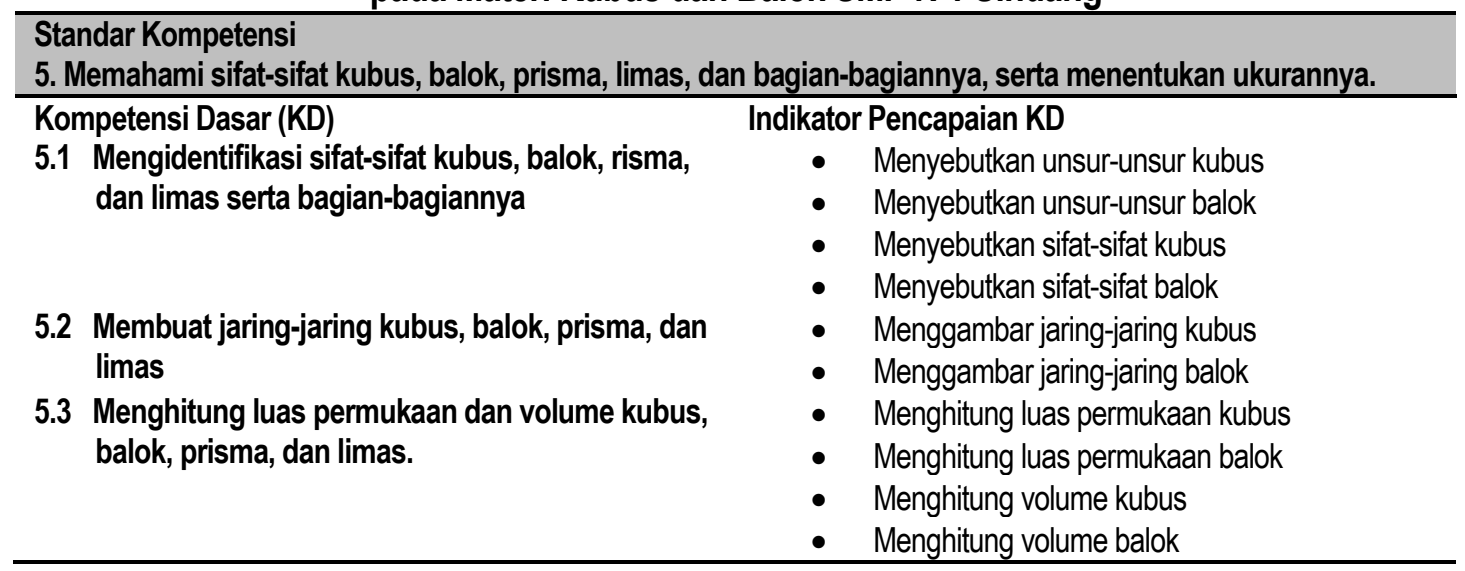

Diperoleh juga hambatan belajar dari hasil observasi tes soal uraian berdasarkan soal-soal berkaitan dengan kehidupan sehari-hari dan sesuai dengan taksonomi bloom. Hambatan belajar dalam proses belajar bukanlah hal yang sepele, melainkan hal yang membutuhkan perhatian khusus dalam menyelesaikannya. Berdasarkan masalah yang ditemukan perlu adanya perangkat pembelajaran yang digunakan khususnya LKS, LKS tersebut haruslah memiliki acuan atau dasar pendekatan. Pendekatan pembelajaran yang digunakan adalah pendekatan kontekstual secara khusus yang dapat mengatasi kesulitan-kesulitan siswa dalam menguasai materi.

Contextual adalah sebuah sisitem belajar yang didasarkan pada filosofi atau menyeluruh, pada proses pembelajarannya siswa dimotivasi sehingga siswa mampu menyerap dan menagkap makna pelajaran dari materi akademis yang mereka terima sesuai konteks pada kehidupan sehari-hari, pada pendekatan kontekstual siswa akan mempunyai pengetahuan dan keterampilan dalam dalam menyelesaikan tugas-tugas sekolahnya sehingga siswa dapat mengkaitkan informasi baru dengan pengetahuan dan pengalamannya yang sudah mereka miliki sebelumnya (Johnson, Elaine B., 2014: 102). 
Menurut Sugiyono (2015) bahwa pengetahuan diperoleh siswa melalui pengalaman yang didapat bukan melalui informasi yang diperoleh guru semata. Guru sebaiknya menghindari proses belajar mengajar sebagai proses penyampaian informasi. Jika dalam proses pembelajaran guru perlu memberikan informasi, maka guru harus memberi kesempatan bagi siswa untuk menggali informasi itu agar lebih bermakna. Menyikapi permasalahan yang muncul maka perlu adanya perangkat pembelajaran yang membawa siswa aktif dan percaya diri terhadap pembelajaran matematika. Salah satunya dengan menerapkan pembelajaran kontekstual.

Menurut Al-Tabany, Trianto Ibnu Badar (2015), kontekstual mempunyai tujuh komponen utama, yaitu: (1) kontruktivisme; (2) menemukan; (3) bertanya; (4) masyarakat belajar; (5) pemodelan; (6) refleksi; dan (7) penilaian nyata. Komponen kontekstual saling terhubung, dapat menolong siswa dalam memahami dan memperoleh pengetahuan.

Dari latar belakang yang telah dipaparkan diatas penulis tertarik menggunakan pendekatan kontekstual sebagai bahan penelitian dengan judul "Pengembangan Perangkat Pembelajaran dengan Pendekatan Kontekstual pada Materi Kubus dan Balok."

Berdasarkan uraian di atas, maka rumusan masalah yang diajukan pada penelitian ini adalah bagaimana merancang pengembangan perangkat pembelajaran berupa RPP dan LKS pada Materi Kubus dan Balok dengan Pendekatan Kontekstual untuk Siswa SMP yang valid?

\section{METODE PENELITIAN}

Dalam penelitain ini peneliti menggunakan jenis penelitian pengembangan dengan maksud mengembangkan perangkat pembelajaran matematika yang ada di SMP Negeri 1 Sindang. Penelitian pengembangan adalah penelitian yang bertujuan untuk mengembangkan produk dan mengetahui kualitas produk yang telah dihasilkan. Produk yang dimaksud dalam penelitian ini adalah Rencana Proses Pembelajaran (RPP) dan Lembar Kerja Siswa (LKS). Metode yang digunakan dalam penelitian ini adalah metode penelitian kuantitatif dan kualitatif.

Inti dari penelitian ini yaitu menyusun pengembangan perangkat pembelajaran terkait materi kubus dan balok dengan pendekatan kontekstual. Model pengembangan perangkat pembelajaran berupa RPP, LKS, dan Pedoman Pembelajaran Guru yang digunakan dalam penelitian ini menggunakan model pengembangan $A D D I E$.

Menurut Hilman dkk. (2015:28), ada beberapa langkah pengembangan model ADDIE. Tahaptahap yang dilakukan adalah: Analisis (Analysis), Desain(Design), Pengembangan(Development), Implementasi (Implementation), danEvaluasi (Evaluation).

Subyek dalam penelitian ini adalah kelas VIII-B SMP Negeri 1Sindang yang terdiri dari 33 siswa. Cara untuk memperoleh data yang diperlukan pada penelitian ini menggunakan instrumen penelitian berupa instrumen tes dan instrumen validasi perangkat pembelajaran.

Instrumen tes dalam penelitian ini berupa soal uraian yang telah diujicobakan sebanyak 10 soal, yang digunakan sebagai tes awal untuk mengetahui hambatan belajar siswa. Soal tersebut diujicobakan terlebih dahulu pada kelas yang telah mendapatkan materi kubus dan balok. Tes uji coba berguna untuk mengetahui validitas, reliabilitas, indeks kesukaran, dan daya pembeda. Selain instrumen tes terdapat instrumen validasi perangkat pembelajaran untuk mengetahui apakah perangkat pembelajaran layak digunakan atau tidak.

Setelah data yang diperlukan terkumpul, maka dilakukan analisis data. Adapun analisis data yang dilakukan dalam penelitian ini adalah sebagai berikut.

Dikirim: 2 Mei 2018; Diterima: 17 September 2018; Dipublikasikan: 29 September 2018

Cara sitasi: Aminah, N., dan Irawati. 2018. Pengembangan Perangkat Pembelajaran dengan Pendekatan Kontekstual pada Materi Kubus dan Balok. Teorema: Teori dan Riset Matematika Vol 3, No 2 (2018). Hal 137-144 


\section{Analisis Validasi Bahan Ajar Berupa LKS dan Pedoman Pembelajaran}

Analisis LKS dan Pedoman Pembelajaran ini bertujuan untuk mengetahui instrumen valid atau tidak, validasi ini dilakukan oleh masing-masing validator dengan menghitung persentasinya untuk mengetahui validitas LKS dan Pedoman Pembelajaran. Menurut Akbar, Sa'dun (2013) untuk mengetahui validitas setiap komponen LKS dan Pedoman Pembelajaran yang divalidasi dengan rumus sebagai berikut.

$$
\operatorname{Vah}=\frac{T S e}{T S h} \times 100 \%
$$

Tabel 2. Kriteria Validitas Bahan Ajar dan Pedoman Pembelajaran oleh Ahli

\begin{tabular}{ccl}
\hline No & Kriteria Validitas & \\
\hline 1 & $85,01 \%-100,00 \%$ & Sangat valid, atau dapat digunakan tanpa revisi. \\
2 & $70,01 \%-85,00 \%$ & Cukup valid, atau dapat digunakan namun perlu direvisi kecil. \\
3 & $50,01 \%-70,00 \%$ & Kurang valid, disarankan tidak digunakan karena perlu revisi besar. \\
4 & $01,00 \%-50,00 \%$ & Tidak valid, atau tidak boleh digunakan. \\
\hline
\end{tabular}

Langkah analisis validasi bahan ajar adalah untuk menentukan kevalidan bahan ajar berupa LKS dan pedoman pembelajaran apakah layak untuk digunakan atau tidak. Selanjutnya tujuan penelitian ini akan digunakan Uji Q-Cochran untuk menyamakan persepsi kelima validator. Menurut Rusyana, dkk (2017) untuk menguji keseragamaan pendapat dari kelima ahli tersebut rumus yang digunakan untuk pengujian adalah sebagai berikut.

$$
Q=\frac{(k-1)\left[k \sum_{j=1}^{k} G_{j}{ }^{2}-\left(\sum_{j=1}^{k} G_{j}\right)^{2}\right]}{k \sum_{i=1}^{N} L_{i}-\sum_{i=1}^{N} L_{i}{ }^{2}}
$$

\section{Analisis Validasi Rencana Pelaksanaan Pembelajaran (RPP) untuk LKS}

Analisis RPP bertujuan untuk mengetahui instrumen valid atau tidak, validasi RPP atau rencana implementasi pembelajaran ini dilakukan oleh masing-masing validator dengan menghitung persentasinya untuk mengetahui validitas RPP. Menurut Akbar, Sa'dun (2013) untuk mengetahui validitas setiap komponen RPP yang divalidasi dengan rumus sebagai berikut.

$$
\operatorname{Vah}=\frac{T S e}{T S h} \times 100 \%
$$

\section{Tabel 3.Kriteria Validasi RPP untuk LKS oleh Ahli}

\begin{tabular}{lll}
\hline No & Kriteria Validitas & Tingkat Validitas \\
\hline 1 & $85,01 \%-100,00 \%$ & Sangat valid,atau dapat digunakan tanpa revisi. \\
2 & $70,01 \%-85,00 \%$ & Cukup valid, atau dapat digunakan namun perlu direvisi kecil. \\
3 & $50,01 \%-70,00 \%$ & Kurang valid, disarankan tidak digunakan karena perlu revisi besar. \\
4 & $01,00 \%-50,00 \%$ & Tidak valid, atau tidak boleh digunakan. \\
\hline
\end{tabular}

Langkah analisis validasi Rencana Pelaksanaan Pembelajaran (RPP) atau Rencana Implementasi Pembelajaran adalah untuk menentukan kevalidan RPP apakah layak untuk digunakan atau tidak. Selanjutnya tujuan penelitian ini akan digunakan Uji Q-Cochran untuk menyamakan persepsi kelima validator. 


\section{HASIL DAN PEMBAHASAN}

\section{Hambatan Belajar Terkait Pendekatan Kontekstual dan Taksonomi Bloom pada Materi Kubus dan Balok}

Didapatkan hasil berdasarkan hambatan belajar perkonsep yang ada pada soal uji coba materi Kubus dan Balok.

a. Hambatan belajar siswa mengenai aspek keterkaitan antara materi dengan menghubungkan konsep aljabar sifat perkalian dan pembagian. Pada soal tersebut siswa dituntut menyelesaikan perhitungan dengan konsep aljabar untuk menyelesaikan masalah volume balok.

b. Hambatan belajar siswa mengenai aspek pemahaman siswa tentang unsur-unsur pada balok. Pada soal tersebut siswa dituntut untuk menyebutkan keenam sisi pada balok dan menghitung panjang diagonal ruang balok dengan tepat.

c. Hambatan belajar siswa mengenai aspek kekeliruan terhadap menggunakan rumus luas permukaan dan volume kubus serta balok. Pada soal tersebut siswa dituntut untuk menuliskan dan menghitung soal cerita yang berkaitan dengan penggunaan rumus luas permukaan dan volume kubus serta balok.

d. Hambatan belajar siswa mengenai aspek pemahaman siswa terkait cara menggambar jaring-jaring balok. Pada soal tersebut siswa dituntut untuk menggambarkan jaring-jaring balok dengan tepat.

\section{Analisis Kurikulum}

Pada tahap analisis kurikulum menunjukkan hasil berupa analisis materi berdasarkan kurikulum yang digunakan di SMP Negeri 1 Sindang, yaitu KTSP 2006, yang telah dijabarkan Standar Kompetensi dan Kompetensi Dasar yang harus dikuasai oleh siswa pada materi Kubus dan Balok kelas VIII. Standar Kompetensi dan Kompetensi Dasar dijadikan dasar acuan untuk menyusun perangkat pembelajaran yang dikembangkan berdasarkan standar isi pada KTSP 2006. Standar Kompetensi yang harus dikuasai siswa adalah: Memahami sifat-sifat kubus, balok, dan bagian-bagiannya, serta menentukan ukurannya. Sedangkan Kompetensi Dasar yang harus dikuasai adalah: Mengidentifikasi sifat-sifat kubus dan balok serta bagian-bagiannya, membuat jaring-jaring kubus dan balok, dan menghitung luas permukaan kubus dan balok.

\section{Pengembangan Perangkat Pembelajaran dengan Pendekatan Kontekstual pada Materi Kubus dan Balok yang Valid}

Pada tahap Desain (Design) dan Pengembangan (Development) mengenai pengembangan perangkat pembelajaran yang dibuat adalah LKS, RPP, dan Pedoman Pembelajaran Guru. Perangkat pembelajaran ini berbasis pendekatan kontekstual dengan soal-soal yang sesuai dengan Taksonomi Bloom. Berikut dijabarkan pengembangan perangkat pembelajaran dalam bentuk LKS, RPP, dan Pedoman Pembelajaran Guru.

\section{a. Lembar Kegiatan Siswa (LKS)}

LKS ini didesain dengan aktivitas siswa yang lebih aktif dari pembelajaran biasanya, sehingga siswa dapat mudah untuk memahami materi kubus dan balok. Tahapan pada LKS ini mengacu pada pendekatan kontekstual dan soal-soal yang sesuai dengan taksonomi bloom. LKS ini bertujuan untuk mengatasi hambatan belajar siswa pada siswa kelas VIII SMP Negeri 1 Sindang.

Dikirim: 2 Mei 2018; Diterima: 17 September 2018; Dipublikasikan: 29 September 2018

Cara sitasi: Aminah, N., dan Irawati. 2018. Pengembangan Perangkat Pembelajaran dengan Pendekatan Kontekstual pada Materi Kubus dan Balok. Teorema: Teori dan Riset Matematika Vol 3, No 2 (2018). Hal 137-144 
Setelah peneliti mendesain dan mengembangkan LKS maka dilakukan tingkat kevalidan LKS apakah layak digunakan dalam proses pembelajaran atau tidak. Validasi ini dilakukan oleh 5 ahli matematika yaitu, 3 orang dosen, dan 2 orang guru. berikut.

Adapun hasil yang diperoleh dari perhitungan validasi setiap validator disajikan pada Tabel 4

Tabel 4. Persentase Penilaian Hasil Validasi LKS

\begin{tabular}{cccccc}
\hline No & Komponen & $\begin{array}{c}\text { Skor } \\
\text { Observasi }\end{array}$ & $\begin{array}{c}\text { Skor yang } \\
\text { Diharapkan }\end{array}$ & $\begin{array}{c}\text { Kriteria } \\
\text { Validitas }\end{array}$ & Interpretasi \\
\hline $\mathbf{1}$ & Validasi Ahli 1 & 81 & 100 & $81 \%$ & Cukup Valid \\
$\mathbf{2}$ & Validasi Ahli 2 & 78 & 100 & $78 \%$ & Cukup Valid \\
$\mathbf{3}$ & Validasi Ahli 3 & 89 & 100 & $89 \%$ & Sangat Valid \\
$\mathbf{4}$ & Validasi Ahli 4 & 90 & 100 & $90 \%$ & Sangat Valid \\
$\mathbf{5}$ & Validasi Ahli 5 & 92 & 100 & $92 \%$ & Sangat Valid \\
\hline
\end{tabular}

Berdasarkan $d k=k-1=5-1=4$ dengan taraf kesalahan 5\% maka harga Chi-Kuadrat tabel $=9,488$. Harga $Q$ hitung 6,67 lebih kecil jika di bandingkan dengan $Q$ tabel. Maka $H_{0}$ diterima dan $H_{a}$ ditolak. Yang berarti tidak terdapat perbedaan pendapat penilaian yang signifikan dari para ahli. Sehingga, dapat disimpulkan bahwa LKS ini layak digunakan atau diimplementasikan pada proses pembelajaran.

\section{b. RPP dengan Pendekatan Kontektual yang Valid}

Pedoman pembelajaran ini didesain dengan memunculkan aktivitas guru sebagai fasilitator, sehingga siswa dapat lebih aktif dalam proses pembelajaran dan dapat memahami materi kubus dan balok. Pada tahap pembelajaran ini sesuai menggunakan tahapan dari pendekatan kontekstual yang sesuai dengan KTSP 2006. Pedoman pembelajaran ini bertujuan untuk membantu guru matematika SMP Negeri 1 Sindang dalam mengimplementasikan LKS yang telah dikembangkan oleh peneliti. Setelah peneliti mendesain pedoman pembelajaran guru maka perlu dilakukan validasi untuk mengetahui tingkat kevalidan pedoman pembelajaran guru apakah layak digunakan dalam proses pembelajaran atau tidak. Validasi ini dilakukan oleh 5 ahli matematika yaitu, 3 orang dosen, dan 2 orang guru. berikut.

Adapun hasil yang diperoleh dari perhitungan validasi setiap validator disajikan padaTabel 5

Tabel 5. Persentase Penilaian Hasil Validasi Pedoman Pembelajaran Guru

\begin{tabular}{cccccc}
\hline No & Komponen & $\begin{array}{c}\text { Skor } \\
\text { Observasi }\end{array}$ & $\begin{array}{c}\text { Skor yang } \\
\text { Diharapkan }\end{array}$ & $\begin{array}{c}\text { Kriteria } \\
\text { Validitas }\end{array}$ & Interpretasi \\
\hline $\mathbf{1}$ & Validasi Ahli 1 & 73 & 80 & $91,25 \%$ & Sangat Valid \\
$\mathbf{2}$ & Validasi Ahli 2 & 62 & 80 & $77,5 \%$ & Cukup Valid \\
$\mathbf{3}$ & Validasi Ahli 3 & 69 & 80 & $86,25 \%$ & Sangat Valid \\
$\mathbf{4}$ & Validasi Ahli 4 & 75 & 80 & $91,46 \%$ & Sangat Valid \\
$\mathbf{5}$ & Validasi Ahli 5 & 72 & 80 & $87,80 \%$ & Sangat Valid \\
\hline
\end{tabular}

Berdasarkan $d k=k-1=5-1=4$ dengan taraf kesalahan $5 \%$ maka harga Chi-Kuadrat tabel $=9,488$. Harga $Q$ hitung 4 lebih kecil jika dibandingkan dengan $Q$ table, maka $H_{0}$ diterima dan $H_{a}$ ditolak. Yang berarti tidak terdapat perbedaan pendapat penilaian yang signifikan dari para ahli. Sehingga, dapat disimpulkan bahwa Pedoman Pembelajaran Guru ini layak digunakan atau diimplementasikan pada proses pembelajaran. 


\section{KESIMPULAN}

Berdasarkan analisis yang dilakukan peneliti, maka diperoleh kesimpulan sebagai berikut.

1. Hambatan belajar yang dialami siswa dalam mengerjakan soal uji coba terkait materi kubus dan balok menjadi 4 tipe, yaitu sebagai berikut.

Tipe 1 : Hambatan belajar mengenai pemahaman unsur-unsur kubus danbalok.

Tipe 2 : Hambatan belajar mengenai pemahaman luas permukaan dan volume kubus serta balok.

Tipe 3 : Hambatan belajar mengenai keterkaitan materi kubus dan balok dengan konsep aljabar sifat perkalian dan pembagian.

Tipe 4 : Hambatan belajar mengenai menggambar jaring-jaring kubus dan balok.

2. Analisis kurikulum berupa analisis materi kubus dan balok yang berdasarkan kurikulum KTSP 2006. Standar Kompetensi dan Kompetensi Dasar dijadikan dasar acuan untuk penyusunan perangkat pembelajaran yang dikembangkan berdasarkan Standar Isi pada KTSP 2006 Standar Kompetensi yang harus dikuasai siswa adalah: Memahami sifat-sifat kubus, balok, dan bagianbagiannya, serta menentukan ukurannya, sedangkan Kompetensi Dasar yang harus dikuasai adalah: Mengidentifikasi sifat-sifat kubus dan balok serta bagian-bagiannya, membuat jaringjaring kubus dan balok, dan menghitung luas permukaan kubus dan balok.

3. Pengembangan perangkat pembelajaran dibuat dengan model pengembangan ADDIE yang disusun berdasarkan hambatan belajar siswa terkait pendekatan kontekstual dan taksonomi bloom, serta disusun berdasarkan analisis kurikulum KTSP 2006. Pada tahap validasi perangkat pembelajaran dilakukan oleh validasi ahli matematika, yang terdiri dari 3 dosen pendidikan matematika, dan 2 guru matematika. Berdasarkan hasil validasi LKS dari kelima validator diperoleh persentasenya sebesar $86 \%$ dengan interpretasi sangat valid, sedangkan untuk menyamakan persepsi berdasarkan hasil uji $Q$ Cochran harga $Q$ hitung 6,67 yang berarti tidak ada perbedaan yang signifikan dari kelima validator tersebut. Selain LKS dikembangkan pula Pedoman Pembelajaran Guru, berdasarkan hasil validasi dari kelima validator diperoleh persentasenya $87,75 \%$ dengan interpretasi sangat valid, sedangkan untuk menyamakan persepsi berdasarkan hasil uji $Q$ Cochran harga $Q$ hitung 4 yang berarti tidak ada perbedaan yang signifikan dari kelima validator tersebut.

4. Pengembangan Rencana Pelaksanaan Pembelajaran untuk membantu guru dalam mengimplementasikan LKS yang dikembangkan. Berdasarkan hasil validasi RPP dari kelima validator diperoleh persentasenya $84,6 \%$ dengan interpretasi cukup valid, sedangkan untuk menyamakan persepsi berdasarkan hasil uji $Q$ Cochran harga $Q$ hitung 5,538 yang berarti tidak ada perbedaan yang signifikan dari kelima validator tersebut.

\section{DAFTAR PUSTAKA}

Akbar, Sa'dun. (2013). Instrumen Perangkat Pembelajaran. Bandung: ROSDA.

Al-Tabany, Trianto Ibnu Badar. (2015). Mendesain Model Pembelajaran Inovatif, Progresif, dan Kontekstual. Jakarta: Prenadamedia Grup.

Aminah, N. (2017). Kemampuan Berfikir Kritis dan Disposisi Matematis. Jurnal Dialektika. Vol 2 No 2. Hal 50-59. ISSN: $2089-4821$.

Dikirim: 2 Mei 2018; Diterima: 17 September 2018; Dipublikasikan: 29 September 2018

Cara sitasi: Aminah, N., dan Irawati. 2018. Pengembangan Perangkat Pembelajaran dengan Pendekatan Kontekstual pada Materi Kubus dan Balok. Teorema: Teori dan Riset Matematika Vol 3, No 2 (2018). Hal 137-144 
Chodijah, Siti, dkk. (2012). Pengembangan Perangkat Pembelajaran Fisika Menggunakan Model Guided Inquiry yang Dilengkapi Penilaian Portofolio pada Materi Gerak Melingkar. Jurnal Penelitian Pembelajaran Fisika. Vo 1 No. 1 Hal. 1-19. ISSN: 2252-3014.

Hilman \& Retnawati, Heri. (2015). Pengembangan Perangkat Pembelajaran Matematika SMP dengan Metode Inkuiri pada Persamaan dan Pertidaksamaan Linear Satu Valiabel. Jurnal Riset Pendidikan Matematika. Volume: 2. Hal. 35-41. ISSN: 2356-2684.

Johnson, Elaine B. (2014). Contextual Teaching \& Learning. Bandung: Kaifa.

Rusyda, Nurul Afifah\& Sari, Dwi Septina. (2017). Pengaruh Penerapan Model Contextual Teaching and Learning Terhadap Kemampuan Pemahaman Konsep Matematis Siswa SMP pada Materi Garis dan Sudut. Jurnal Nasional Pendidikan Matematika. Volume: 1. ISSN: 2549-8495.

Sugiyono. (2015). Statistik Nonparametris untuk Penelitian. Bandung: Alfabeta. 